DOI: 10.34015/2523-4552.2020.3.09

УДК 355.9

\begin{abstract}
Колб О. Г., доктор юридичних наук, професор, заслужений юрист Украӥни, професор кафедри політології, управління та державної безпеки Волинського національного університету імені Лесі Українки ORCID: 0000-0003-1792-4739
\end{abstract}

Колб Р. 0 ., аспірант Волинського національного університету імені Лесі Українки ORCID: 0000-0003-0187-3391

\title{
НОРМАТИВНО-ПРАВОВІ НЕУЗГОДЖЕНОСТІ ТА СУПЕРЕЧНОСТІ ІНФОРМАЦІЙНОЇ ДІЯЛЬНОСТІ - ОДНА ІЗ ЗАГРОЗ НАЦІОНАЛЬНОЇ БЕЗПЕКИ УКРАЇНИ
}

У статті здійснено аналіз змісту основних нормативно-правових актів, які регулюють питання інформаційної діяльності та безпеки в Україні, визначені змістовні елементи їх співвідношення, неузгодженості та суперечності, а також розроблені науково обгрунтовані шляхи усунення останніх у контексті змісту положень національної безпеки.

Встановлено, що у сьогоднішніх умовах при прийнятті законів та інших нормативно-правових джерел з означеної проблематики, суб'єкти нормотворчої діяльності не тільки порушують принцип верховенства права, що визначений в ст. 8 Конституції України, але й інших ії норм, які стосуються інформаційної безпеки як об'єкта правової охорони, що, у свою чергу, породжує скарги громадян у різні судові та державні органи, а також до недотримання основоположних прав і законних прав людини, які $є$ загальновизнаними у міжнародному праві та $€$ предметом захисту у Європейському суді з прав людини.

Доведено також, що таке положення з питань забезпечення інформаційної безпеки не тільки підриває авторитет нашої держави на міжнародній арені, але й виступає однією із загроз національної безпеки України.

Ключові слова: нормативно-правовий акт; інформаційна безпека; національна безпека; загроза; запобігання; суб'єкти нормотворчості; суд; неузгодженість; суперечність.

В статье проведен анализ содержания основных нормативно-правовых актов, регулирующих вопросы информационной деятельности и безопасности в Украине, определены содержательные элементы их соотношения, несогласованности и противоречия, а также разработаны научно обоснованные пути устранения последних в контексте содержания положений национальной безопасности. 
Установлено, что в сегодняшних условиях при принятии законов и других нормативно-правовых источников по обозначенной проблематике, субъекты нормотворческой деятельности не только нарушают принцип верховенства права, определен в ст. 8 Конституции Украины, но и других ее норм, касающихся информационной безопасности как объекта правовой охраны, что, в свою очередь, порождает жалобы граждан в различные судебные и государственные органы, а также к несоблюдению основополагающих прав и законных прав человека, которые являются общепризнанными в международном праве и является предметом защиты в Европейском суде по правам человека.

Доказано также, что такое положение по вопросам обеспечения информационной безопасности не только подрывает авторитет нашего государства на международной арене, но и выступает одной из угроз национальной безопасности Украины.

Ключевые слова: нормативно-правовой акт; информационная безопасность; национальная безопасность; угроза; предупреждения; субъекты нормотворчества; суд; несогласованность; противоречие.

Постановка проблеми. Як зазначено в ст. 31 Конституції України, кожному гарантується таємниця листування, телефонних розмов, телеграфної та іншої кореспонденції. Винятки можуть бути встановлені лише судом у випадках, передбачених законом, з метою запобігти злочинові чи з'ясувати істину під час розслідування кримінального провадження, якщо іншими способами одержати інформацію неможливо [1].

Аналогічні положення закріплені й в інших статтях Основного закону України. Так, у ч. ч. ст. 32 Конституції України мова ведеться про те, що не допускається збирання, збереження та поширення конфіденційної інформації про особу без ії згоди, крім випадків, визнаних законом, і лише в інтересах національної безпеки, економічного добробуту та прав людини.

Як у зв'язку з цим зазначено в п. 3 рішення Конституційного Суду України від 20.01.2012 №2-рп/2012, лише фізична особа, якої стосується конфіденційна інформація, відпо- відно до конституційного та законодавчого регулювання прав особи та збирання, використання та поширення конфіденційної інформації має право вільно, на власний розсуд визнати порядок ознайомлення 3 нею інших осіб, держави та органів місцевого самоврядування, а також на збереженні її у таємниці [2].

Здавалось би, що на конституційному рівні створені належні умови для забезпечення інформаційної безпеки в Україні. Проте, практика свідчить про суттєві правові прогалини, суперечності та неузгодженості не тільки між нормами Конституції України та законами і іншими нормативно-правовими актами, що регулюють питання інформаційної діяльності в нашій державі. Мова, у першу чергу, ведеться про захист конфіденційної інформації про особу без іiї згоди. Зокрема, досить поширеними у сьогоденні $\epsilon$ так звані «журналістські розслідування», які нічого спільного з положеннями законів, що регулюють діяльність журналістів в Україні [3] не мають. Так, лише у 2019-2020 pp. у результаті 
втручання в особисте життя «жертвами» поширення зібраними протиправним шляхом інформації стали декілька депутатів партії «Слуга народу» [4], «Європейської Солідарності» [5] та інших представників влади.

Ще далі $з$ цього приводу пішли правоохоронці, які у 2014-2018 рр. на засіданні Верховної Ради України у відкритому режимі розсекретили (оприлюднили публічно) інформацію про народних депутатів, яка була предметом слідчої таємниці (одного з видів державної таємниці [6]), що привело до нівелювання (знеціню-вання) зібраних щодо підозрюваних осіб доказів її вини у кримінальному провадженні [7].

Зазначені та інші факти свідчать про те, що в наявності складна прикладна проблема, яка має бути вирішена, у тому числі й на доктринальному рівні.

Постановка завдання. Виходячи 3 цього, основною метою даної наукової статті $\epsilon$ визначення правових прогалин, суперечностей i неузгодженостей, що пов'язані із забезпеченням інформаційної безпеки в Україні, а її головним завданням - розробка науково обгрунтованих заходів, спрямованих на удосконалення правового механізму з означених питань та зменшення рівня загроз у зв'язку з цим національній безпеці України.

Аналіз останніх досліджень i публікацій. Як показали результати вивчення наукової літератури, досить активно розробкою проблем, пов'язаних із змістом національної безпеки України, займаються такі учені, як: О. М. Бандурка, В. Т. Білоус, Ю. П. Битяк, В. П. Горбулін, О. А. Делінський, В. В. Голіна, Б. М.Головкін,
В. С. Карташов, С. В. Ківалов, О. В. Копан, I. М. Копотун, В. Я. Колпаков, М. В. Левицька, В. А. Ліпкан, В. П. Пєтков, Г.П. Ситник, В.Ф. Сіренко, О. Л. Хилько, З. Д. Чуйко, Ю. С. Шемшученко та ін.

Поряд 3 цим, у сучасних суспільно-політичних та військових умовах, що склались в Україні, питання більш ефективного та продуктивного забезпечення національної безпеки набувають підвищеної уваги та потребують вирішення на доктринальному рівні, що й стало вирішальним при виборі предмета даної наукової статті.

Виклад основного матеріалу. Для того, щоб зрозуміти у повній мірі сутність досліджуваної проблематики, без сумніву, варто проаналізувати зміст ключових термінів, які використовуються у нормативноправових актах 3 питань інформаційної та національної безпеки України. При цьому слід зазначити, що корінним у них $є$ слово «інформація», під якою у наукових джерелах розуміють будь-які дані або відомості, які кого-небудь цікавлять (походить від грецького слова «informatio» - роз'яснення, викладене усно або письмово) [8].

У свою чергу, в ст. 1 Закону України «Про інформацію» такою вважають будь-які відомості та/або дані, які можуть бути збережені на матеріальних носіях або відображені в електронному вигляді [9].

Отже, якщо узагальнити доктринальні та нормативно-правові підходи, то слово «інформація» означає відповідні відомості про фізичну особу, групу цих осіб, а також про юридичних осіб, окремих їх груп та держав, що на законних підставах зібрані, зберігаються, використову- 
ються та поширюються іншим суб'єктом, а також відображені в усній або письмовій формі (на матеріальних носіях або в електронному вигляді).

У більш вузькому змісті, як це витікає із змісту преамбули Закону України «Про інформацію», про інформацію слід вести мову у контексті їі створення, збирання, одержання, зберігання, використання, поширення, охорони та захисту [9].

Немаловажне значення, у сенсі завдань, які мають бути вирішені у ході даної наукової розробки, має також слово «безпека» [10], під яким в науці розуміють відсутність загроз [3].

Таким чином, якщо узагальнити зазначені вище слова, то термін «інформаційна безпека» має означати в буквальному змісті таку діяльність по створенню, збиранню, одержанню, зберіганню, використанню, поширенню, охороні та захисту відомостей про будь-яку фізичну та юридичну особи, а також інші об'єкти життєдіяльності та в цілому про навколишнє середовище.

Якщо при цьому розглянути це питання у контексті діяльності журналістів, то можна у зв'язку з цим виокремити наступні особливості їі нормативно-правового забезпечення, а саме:

1. Закріпивши у розділі III Закону України «Про інформацію» правові засади діяльності журналістів, засобів масової інформації, їх працівників, законодавець не надав право зазначеним суб'єктам займатись оперативно-розшуковою діяльністю (ОРД) та здійснювати інші негласні заходи.

Такий висновок грунтується на положеннях: а) ст. 5 Закону України «Про оперативно-розшукову діяльність» [11] не відносить до суб'єктів ОРД журналістів та працівників засобів масової інформації (ЗМI), а тому вони не вправі збирати, використовувати, розповсюджувати будь-які відомості про фізичну чи юридичну особу, які відносяться до конфіденційної, таємної або службової інформації (ст. 21 Закону України «Про інформацію»).

3 цього випливає, що діяльність тих журналістів, які збирають та поширюють негласним чином інформацію про представників влади (Президента України, Кабінет Міністрів, народних депутатів, таке інше) діють незаконно, позаяк перевищують свої повноваження та порушують визначені у Законі «Про інформацію» принципи (ст. 1), 3окрема: принципу правомірності одержання, використання, поширення, зберігання та захисту інформації, а також принципу захищеності особи від втручання в її особисте та сімейне життя.

Саме $з$ цих міркувань, незаконною слід визнати діяльність тих журналістів, що останнім часом (2014-2020 рр.), збираючи «сенсаційні» відомості про керівництво держави та окремих народних депутатів 3 питань їх особистого та сімейного життя;

б) ст. 246 Кримінального процесуального кодексу України «підстави проведення негласних слідчих (розшукових) дій [12], відповідно до змісту якої журналісти та інші працівники 3MI не відносяться також i до тих учасників кримінального провадження, які вправі проводити зазначені процесуальні заходи. 
Отже, здійснення журналістами та іншими працівниками 3МI негласних заходів не тільки посягає на особисту безпеку особи, але й відноситься до однієї із загроз національної безпеки, особливо у випадках, коли її об'єктами є представники влади найвищого рівня (народні депутати, зокрема).

2. Одним із основних напрямів державної інформаційної політики України (ст. 3 Закону України «Про інформацію») $\epsilon$ забезпечення інформаційної безпеки.

Враховуючи зазначене та види інформації (ст.10 Закону України «Про інформацію»), зокрема такої із них, як інформація про фізичну особу (відомості чи сукупність відомостей про фізичну особу, яка ідентифікована або може бути конкретно ідентифікована), не можна вважати законною сьогоднішню практику розповсюдження 3MI інформації, отриманої від деяких учасників кримінального провадження (слідчих, прокурорів, керівництва MBC України чи Національної поліції) про підозрюваних осіб, позаяк, як це витікає із змісту ст. 62 Конституції України, особа вважається невинуватою у вчиненні злочину доки її вину не буде доведено в законному порядку і встановлено обвинувальним вироком суду.

Наочним прикладом такого «беззаконня» $\epsilon$ розповсюдження інформації, яка носила обмежений характер, можна назвати оприлюднену у 2014-2020 рр. на засіданні Верховної Ради України у відкритому режимі відомості про деяких народних депутатів, щодо яких Генеральний прокурор України вніс подання про притягнення до кримінальної відповідальності, що, в кінцевому результаті, привело до втрати доказової бази та закриття кримінальних проваджень, а також створило одну із загроз національній безпеці України, позаяк була розголошена слідча таємниця (ст. 222 КПК).

Таким чином, конфіденційна інформація про особу, доступ до якої обмежено фізичною або юридичною особою (у приведеному вище прикладі - слідчим чи прокурором у ході досудового розслідування щодо підозрюваних у вчиненні злочину народних депутатів), не може бути поширена без дозволу останніх, а тому представники 3MI у таких ситуаціях мають чітко дотримуватись норм Конституції та інших законів, а також основних принципів інформаційних відносин (ст. 2 Закону України «Про інформацію»), зокрема принципу правомірності одержання, використання, поширення, збереження та захисту інформації, а також принципу захищеності особи від втручання в іiі особисте сімейне життя.

3. Відповідно до вимог ст. 5 Закону України «Про інформацію», реалізація прав журналістів та інших працівників 3МІ на основні види інформаційної діяльності (ст.9) не повинна порушувати громадські, політичні, економічні, соціальні, духовні, екологічні та інші права, свободи і законні інтереси інших громадян, права та інтереси юридичних осіб. При цьому слід зазначити, що у такому ж порядку має реалізуватись працівниками ЗМI й та інформація, яка не віднесена до відомостей з обмеженим доступом (ч. 4 ст. 21 Закону України «Про інформацію»).

4. Однією із гарантій права журналістів та інших працівників ЗМІ на інформацію $є$ встановлення на законодавчому рівні відповідаль- 
ності за порушення законодавства про інформацію (ст. 6 Закону України «Про інформацію»).

Як показали результати вивчення нормативно-правових основ тих актів, що стосуються інформаційної діяльності в Україні, до видів і засобів забезпечення юридичної відповідальності суб'єктів інформаційних відносин (ст. 4 Закону України «Про інформацію») (дисциплінарну, цивільно-правову, адміністративну або кримінальну) можна віднести наступні:

а) дисциплінарна відповідальність журналістів та інших працівників 3МІ регулюється нормативно-правовими актами 3 питань журналістської діяльності (Статутами, Положеннями, т. ін., які носять локальний характер та $\epsilon$ предметом розгляду та реагування на проступки роботодавцем);

б) цивільно-правова відповідальність визначена в Цивільному кодексі (ЦК) України [13]. Зокрема, у ст. ст. 22-23, 275 ЦК фізична особа має право на захист свого особистого немайнового права від протиправних посягань інших осіб тими способами, що встановлені в главі 3 цього Кодексу;

в) адміністративна відповідальність 3 означених інформаційних відносин визначена в ст. ст. 1731, 185-11, 186-3, ін. Кодексу України про адміністративні правопорушен- ня (КУПАП) за поширення неправдивої інформації [14];

г) кримінальна відповідальність за означені протиправні діяння (ст. ст. 328, 330, 361 - 363-1 Кримінального кодексу України (КК).

Висновки. Таким чином, як показав короткий аналіз нормативноправових актів, що стосуються інформаційної діяльності в Україні, вони не тільки не кореспондуються поміж собою, особливо в частині збирання, використання та поширення відомостей про фізичну особу, але й з нормами Конституції України, які, з одного боку гарантують право на свободу думки і слова, а також на вільне вираження своїх поглядів і переконань, a, з іншого, обмежують це право в інтересах безпеки з метою захисту репутації або прав інших людей, для запобігання розголошенню інформації, одержаної конфіденційно, або для підтримання авторитету і неупередженості правосуддя (ст. 34 Основного закону України).

Виходячи $з$ цього, цілком очевидним на сьогодні $є$ удосконалення правового механізму 3 питань інформаційних відносин в Україні, а також журналістської діяльності 3 означених у законі основних напрямах державної інформаційної політики (ст. 3 Закону України «Про інформацію»), з метою усунення однієї із загроз національної безпеки в нашій державі.

\section{Список використаних джерел}

1. Конституція України: прийнята 28 червня 1996 року (із змінами станом на 02.12.2019). URL: https://zakon.rada.gov.ua (дата звернення: 22.09.2020).

2. Рішення Конституційного Суду України у справі за конституційним поданням Жашківської районної ради Черкаської області щодо офіційного тлумачення положень частини першої, другої статті 32, частини другої, третьої статті 34 Конституції України №2-рп/2012 від 20 січня 2012 року. URL: https://zakon.rada.gov.ua (дата звернення: 12.09.2020). 
3. Правові засади діяльності журналістів в Україні: роз'яснення Міністерства юстиції України від 04.10.2011. URL: https://zakon.rada.gov.ua (дата звернення: 02.09.2020).

4. Журналісти зловили нардепа Яременка на листуванні в Раді з повією. Він заявив, що ловив їх на підгляданні. URL: https://nv.ua/ukr/ukraine/politics/bogdanyaremenko-skandal-u-sluzi-narodu-novini-ukrajini-50050642.html (дата звернення: 12.09.2020).

5. «Плівки Деркача»: як Україна знову опинилася в епіцентрі міжнародного скандалу - думки експертів. URL: https://www.5.ua/polityka/plivky-derkacha-iakukraina-znovu-opynylysia-v-epitsentri-mizhnarodnoho-skandalu-dumky-ekspertiv-

221764.html (дата звернення: 12.09.2020).

6. Про державну таємницю: Закон України від 21.01.1994 р. (редакція станом на 15.08.2020). URL: https://zakon.rada.gov.ua (дата звернення: 12.09.2020).

7. «Бурштинова справа». URL: https://nabu.gov.ua/novyny/burshtynova-sprava (дата звернення: 12.09.2020).

8. Булыко А. Н. Большой словарь иностранных слов. 35 тысяч слов. Изд. 3-е, испр., перераб. Москва: Мартин, 2010. 704 с.

9. Про інформацію: Закон України від 02 жовтня 1992 року (в редакції від 16.07.2020). URL: https://zakon.rada.gov.ua (дата звернення: 04.09.2020).

10. Современные европейские традиции и концепции национальной безопасности. URL: www.belvpo.com/r4/33942.html (дата звернення: 12.09.2020).

11. Про оперативно-розшукову діяльність: Закон України від 18.02.1992 p. URL: https://zakon.rada.gov.ua (дата звернення: 02.09.2020).

12. Кримінальний процесуальний кодекс України: прийнятий 13 квітня 2012 року. URL: https://zakon.rada.gov.ua (дата звернення: 02.09.2020).

13. Цивільний кодекс України: прийнятий 16 січня 2003 року. URL: https://zakon.rada.gov.ua (дата звернення:11.09.2020).

14. Кодекс України про адміністративні правопорушення: прийнятий 07 грудня 1984 p. URL: https://zakon.rada.gov.ua (дата звернення: 02.09.2020).

15. Кримінальний кодекс України: прийнятий 05 квітня 2001 року. URL: https://zakon.rada.gov.ua (дата звернення: 07.09.2020).

A. Kolb, Professor of the Department of Political Science, Management and State Security of Lesya Ukrainka Volyn National University, Doctor of Law, Professor, Honored Lawyer of Ukraine

ORCID: 0000-0003-1792-4739 Ukrainka

$\boldsymbol{R}$ Kolb, Postgraduate student of Volyn National University named after Lesya

ORCID: 0000-0003-0187-3391

\section{Legal inconsistencies and contradictions of information activity - one of the threats to national security of Ukraine}

The article analyzes the content of the main normative legal acts regulating the issues of information activities and security in Ukraine, identifies the content elements of their correlation, inconsistencies and contradictions, and also elaborates scientifically substantiated ways to eliminate the latter in the context of the content of the provisions of national security. 
It has been established that in today's conditions, when adopting laws and other normative legal sources on the designated issues, the subjects of rule-making activity not only violate the principle of the rule of law, as defined in Art. 8 of the Constitution of Ukraine, but also its other norms concerning information security as an object of legal protection, which, in turn, gives rise to complaints from citizens to various judicial and state bodies, as well as to non-observance of fundamental rights and legal human rights, which are generally recognized in the international law and is subject to protection in the European Court of Human Rights.

It has also been proven that such a provision on information security not only undermines the authority of our state in the international arena, but also acts as one of the threats to the national security of Ukraine.

Keywords: normative legal act; Information Security; National security; the threat; warnings; subjects of rule-making; court; inconsistency; contradiction. 